\title{
Pengaruh Shopping Lifestyle dan Hedonic Motives terhadap Impulse Buying Behavior pada Konsumen Produk Fashion
}

\section{The Influence of Shopping Lifestyle and Hedonic Motives on Impulse Buying Behavior in Fashion Product Consumers}

\author{
Jeni Randyka Putra ${ }^{1}$, Soffy Balgies ${ }^{*}$ \\ ${ }^{1}$ Fakultas Psikologi dan Kesehatan, Universitas Islam Negeri Sunan Ampel Surabaya \\ *soffybalgies@uinsby.ac.id
}

\begin{abstract}
Abstrak
Studi ini untuk mengetahui hubungan antara shopping lifestyle dan hedonic motives terhadap impulse buying behavior pada konsumen produk fashion. Metode yang digunakan adalah kuantitatif dengan menggunakan penelitian survey serta. Teknik pengambilan sampel menggunakan teknik non probability sampling dengan sampel yang berjumlah 140 responden. Teknik pengumpulan data ini menggunakan kuesioner dengan bantuan SPSS versi 20 serta analisis data dalam penelitian ini menggunakan analisis regresi linier berganda. Hasil penelitian menunjukkan $F=48.640$ serta signifikansi $0,000<\alpha=0,05$ bahwa terdapat hubungan yang signifikan. Sehingga shopping lifestyle dan hedonic motives terdapat hubungan yang signifikan terhadap impulse buying behavior pada konsumen produk fashion.
\end{abstract}

Kata Kunci : Shopping Lifestyle, Hedonic Motives, Impulse Buying Behavior, Fashion

\begin{abstract}
This study determine the relationship between shopping lifestyle and hedonic motives on impulse buying behavior in consumers of fashion products. The method used in this research is quantitative by using survey research methods as well. The sampling technique used non-probability sampling techniques with a sample of 140 respondents. This data collection technique used a questionnaire with the help of SPSS version 20 and data analysis in this study using multiple linear regression analysis. The results showed that $\mathrm{F}=48,640$ and a significance of $0,000<\alpha=0.05$, that there is a significant relationship. So that shopping lifestyle and hedonic motives have a significant relationship to impulse buying behavior in consumers of fashion products.
\end{abstract}

Keywords : Shopping Lifestyle, Hedonic Motives, Impulse Buying Behavior, Fashion

\section{Pendahuluan}

Globalisasi dapat mempengaruhi semua aspek di dalam masyarakat. Diantaranya ada aspek kebudayaan yang dapat diartikan nilai - nilai yang dianut masyarakatnya, baik dari segi nilai yang berkaitan hingga aspek kejiwaan dan psikologinya. Sebagian besar pertumbuhan ekonomi didorong oleh pengeluaran para konsumen, terutama pada produk fashion berdasarkan dari kebutuhan primer manusia.

Adapun para pengusaha ritel fashion yang menjual pakaian pria dan wanita dengan seluruh tingkatan usia ini antara lain H\&M, Uniqlo, Zara, yang mendominasi pasar fashion yang ada di Indonesia terutama di Surabaya (jawapos.com). The Asian parent melakukan analisis pada tahun 2017 menemukan hasilnya $73 \%$ populasi masyarakat di Indonesia melakukan pembelian impulsif, Adapun menurut Radityo Triatmojo produk fashion (pakaian) pada saat ini yang menjadi produk paling terlaris hampir 70\% (Kompas.com). 
Pembelian secara impulsif sendiri dapat diartikan kegiatan berbelanja yang dilakukan saat konsumen melihat kategori produk atau barang, selanjutnya konsumen akan tertarik untuk membelinya, dikarenakan terdapat ransangan memikat dari penjualnya (Utami, 2010). Keinginan untuk membeli biasanya muncul ketika konsumen sudah berada di toko atau mall (Mowen dan Minor, 2012).

Selain itu, impulse buying behavior memiliki aspek yang dapat mempengaruhi dari tindakan (Verplanken, 2011). Hal yang dapat menjadi pengaruh dalam tindakan impulsif : 1) Aspek afektif : ini berkaitan emosional individu yang hanya memikirkan kepuasan dan ketertarikan untuk membeli suatu barang, memiliki rasa untuk membeli, susah untuk meninggalkan barang yang akan dibeli, dan kemudian muncul rasa menyesal dan bersalah setelah membeli. 2) Aspek kognitif : ini berkaitan dengan adanya kekurangan persiapan dan pertimbangan matang pada pembuatan keputusan dalam membeli suatu barang.

Individu tidak melakukan evaluasi untuk barang yang dibeli dibutuhkan ataua sekedar hanya ingin. Faktor pribadi dalam diri seseorang yang merupakan faktor penting dari proses pembelian dalam diri konsumen salah satunya adalah gaya hidup belanjanya (Maruf, 2006). Pembelian impulsif ini juga memiliki hubungannya dengan nilai motivasi hedonik. Konsumen akan merasa lebih membaik setelah melakukan tindakan pembelian secara impulsif (Rook dan Hoch, 1985).

Penelitian ini akan berfokus pada pengaruh dari shopping lifestyle serta hedonic motives terhadap impulse buying behavior. Selanjutnya, disetiap diri seseorang tentunya memiliki gaya berbelanja yang berbeda. Shopping lifestyle ini dalam perkembangan kemajuan teknologi di era modern ini memilik kaitannya. Levy (2009) menjelaskan shopping lifestyle ini ialah kebiasaan lifestyle dari mereka menjalankan kehidupannya, kemudian cara kebiasaanya mereka mengalokasikan uang, keadaan serta pendapat individu pada lingkungan sekitar tempat tinggalnya. Kemudian Japarianto (2011) juga menjelaskan shopping lifestyle merupakan cara pengekspresian individu tentang bagaimana gaya hidupnya dalam melakukan tindakan berbelanjanya yang mencerminkan atas status sosialnya.

Adapun shopping lifestyle menurut (Darma, 2014) yang digambarkan sebagai berikut : 1) Kegiatan (activities) dimana cara hidup seseorang yang bertujuan untuk menunjukan perbedaan status sosialnya. 2) Minat (interest) mereka menganggap lingkungan penting untuknya. 3) Opini (opinion) seseorang yang memikirkan tentang dirinya serta dimana lingkungan tempat tinggalnya.

Berbelanja akan menjadikan cara lifestyle keseharian individu, dalam memenuhi kebutuhan kehidupan individunya. Kegiatan semacam ini yang membuat individu memiliki kecendurungan untuk menjadi hedonis. Saat berbelanja secara hedonis konsumen sering mengalami gairah secara emosional yang cenderung tinggi, motif-motif inilah yang biasa disebut dengan motif hedon (Hirschman, 1982).

Penelitian Lumintang (2012) menyebutkan shopping lifestyle terhadap impulse buying mempunyai pengaruh signifikan. Dari hasil ini Lumintang menunjukan tingginya gaya berbelanja pada individu maka tingkatan pembelian impulse ini juga akan membesar kemungkinannya. Rasa perasaan bersalah akan muncul setelah melakukan tindakan pembelian secara impulse (Verplanken, 2011). Dengan demikian, peneliti berargumentasi bahwa hipotesis 1: Shopping lifestyle terhadap impulse buying mempunyai pengaruh signifikan.

Hedonic motives dapatkan dikatakan dari penilaian terhadap manfaat dari pengalaman dan pengorbanan dalam mendapatkan suatu rekreasi (Overby, 2006). Konsumen berbelanja sekedar mengikuti trend yang sedang ramai. Hal ini dikarenakan, gaya hidup berbelanja individu secara hedonis tidak bisa mempertimbangkan manfaat dari suatu produk yang menyebabkan impulsenya akan tinggi.

Adapun kategori yang bisa dipake untuk mengukur motivasi hedonik yang lebih rinci menurut (Arifianti, 2010). Di dalam setiap kategori motivasi hedonik ini terdapat indikator masing-masing, yaitu: 1) Adventure shopping adalah petualangan berbelanja, dan membangkitkan semangat diri seseorang. 2) Social shopping adalah tindakan berbelanja dilakukan bersama keluarga serta temannya. 3) Gratification shopping adalah kondisi hati setiap orang disaat melakukan pembelian dengan tujuannya untuk menghilangkan kebosanan, dan mereka akan selalu menyempatkan waktu yang dimiliki untuk berbelanja. 4) Idea shopping adalah mengikuti trend serta mode yang terbaru, dan melihat adanya produk terbaru dari merk tertentu. 5) Role shopping adalah alasan setiap orang belanja. 6) Value shopping adalah penawaran yang memikat.

Para konsumen disaat melakukan tindakan berbelanja akan selalu mengikuti trend sampai mode yang terkini. Dengan adanya motivasi hedonis dan gaya hidup berbelanja dalam diri sesorang 
maka impulse buying kemungkinan dapat mempengaruhinya, semakin tingginya motivasi hedonis didalam setiap orang, maka tindakan impulse juga bisa semakin tinggi.

Hal tersebut sejalan pada penelitian yang dilakukan Japarianto (2011) menjelaskan hedonic shopping serta fashion involvement terhadap tindakan impulse dikalangan masyarakat pendapatan perkapita yang tinggi di Surbaya mempunyai pengaruh signifikan. Pada penelitian Japarianto menjelaskan juga hedonic shopping juga memiliki pengaruh terhadap impulse buying. Tindakan belanja impulsif dengan hedonis ini selalu terjadi pada individu ketika melakukan pembelian. Dengan demikian, peneliti berargumentasi bahwa hipotesis 2: Hedonic motives terhadap impulse buying mempunyai pengaruh signifikan.

Penelitian terdahulu menunjukan bahwa hasil hedonic shopping motives terhadap impulse buying mempunyai pengaruh signifikan, dan shopping lifestyle terhadap impulse buying mempunyai pengaruh signifikan. Perasaan bersalah yang cukup mengganggu ini disebabkannya kebiasaan berbelanja secara impulsif pada seseorang. Peneliti menduga, bahwa hedonic motives dan shopping lifestyle dapat mempengaruhi perilaku impulse buying seseorang. Dengan demikian, peneliti berargumentasi bahwa hipotesis $3:$ Shopping lifestyle serta hedonic motives terhadap impulse buying mempunyai pengaruh signifikan.

\section{Metode Penelitian}

\section{Subjek}

Sesuai dari dasar tujuan utama pada penelitian dan berdasarkan karakteristiknya ini, maka subjek yang diambil yaitu konsumen yang sering membeli produk fashion seperti Uniqlo, Zara, HnM dengan deretan teratas merupakan produk fashion paling laris. Dalam penelitian ini peneliti menggunakan sebanyak 140 responden. Dasar dilakukan sebuah peneltian, ialah untuk mencari tahu seberapa besar pengaruh dari shopping lifestyle serta hedonic motives trhadap impulse buying behavior.

Variabel - variabel yang diteliti yaitu shopping lifestyle, hedonic motives serta impulse buying behavior yang akan di jelaskan lebih detail sebagai berikut: Impulse buying merupakan tindakan yang dilakukan dengan ketidaksengajaan dan besar kemungkinannya memiliki berbagai macam motif yang dasarnya tidak disadari, sampai dengan reaksi emosional yang cukup kuat (Astrid, 2003), shopping lifestyle merupakan ekspresi dalam gaya hidupnya ketika melakukan pembelian yang bisa membuat status sosial mereka berubah (Betty Jackson, 2004), motivasi hedonis merupakan proses yang didasari dari psikologis dimana dari gerakan perilaku individu serta dengan adanya reaksi yang dilakukan dalam tujuan mendapatkan kesenangannya (Lubis, 2017).

\section{Pengumpulan Data}

Jenis penelitian memakai kuantitatif dengan metode survey dan memakai data skala likert. Tata cara pengambilan data ini dikarenakan dimana adanya keterbatasan jarak antara responden dengan peneliti, maka peneliti menggunakan alat bantu sebaran kuesioner melalui google form, kemudian membagikan link memakai alat ukur pada yang berbeda dalam setiap variabel, untuk kuesioner Impulse Buying Tedency (IBT) yang diadaptasi dari penelitian Verplanken (2001) yang terdiri dari 15 aitem. Kemudian ada kuesioner shopping lifestyle memakau kuesioner dari Anastasia (2018) yang terdiri dari 5 aitem. Kuesioner hedonic motives yang diadaptasi dari penelitian Anastasia (2018). Didalam penelitian ini terdapat teknik sampling yaitu dengan menggunakan teknik sampling insidental, sampel berdasarkan tidak adanya kesengajaan berjumpa serta orang yang ditemui tepat untuk jadikan subjek.

\section{Analisis Data}

Tahap pertama dilakukan uji reliabilitas serta validitas terlebih dahulu pada alat ukurnya guna bertujuan agatr mencari tahu alat ukurnya yang digunakan ini bisa digunakan atau tidak. Dalam tahap untuk mengukur reliabilitas instrumen dipenelitian ini, peneliti juga menggunakan teknik Alpha Cronbach dengan tujuan mengetahui apakah indikator - indikator apa saja tidak digunakan lagi, guna untuk mencapai nilai reliabilitas baik. Lalu proses uji validitas ini guna mencari tahu instrumen dari penelitiannya akan dipergunakan dalam mengukur variabel ini valid atau tidak. Hasilnya menunjukan: 
Tabel 1. Hasil Uji Realibilats dan Validitas

\begin{tabular}{lcc}
\hline \multicolumn{1}{c}{ Variabel } & Cronbach's Alpha & N of Items \\
\hline Impulse Buying Behavior & 0.918 & 8 \\
Shopping Lifestyle & 0.851 & 5 \\
Hedonic Motives & 0.892 & 8 \\
\hline
\end{tabular}

Sumber: Data Pribadi, 2020

Hasil menunjukan bahwasanya nilai dari cronbach alpha seluruh variabel berkisar antara 0 sampai dengan 1, maka dari semua aitem yang ada didalam instrumen pengukurannya bisa diputuskan reliabel. Kemudian untuk range validity menunjukan bahwasanya semua aitem diketiga variabel berada diantara 0 sampai dengan 1, setelah hasil menunjukan dapat diputuskan demikian semua aitem diinstrumen pengukuran ini valid.

Kemudian untuk langkah selanjutnya terdapat analisis deskriptif serata regresi linier berganda, untuk penjelasannya : 1) Analisis deskriptif, ialah guna untuk mengetahui serta mengenal kriteria dari variabel penelitian, dan bisa mendapatkan informasi data diri responden. Kemudian juga menguraikan dari data diri responden tentang ciri khas serta menguraikan respon seseorang ketika ada disuatu lingkungan (Nuryaman, 2015) . 2) Analisis regresi linier berganda, pengujian hipotesis yang pergunaannya dipenelitian ialah menentukan kuatnya pengaruh yang terjadi divariabel independen (Sugiyono, 2013).

\section{Hasil Penelitian}

Data diri demografis jenis kelamin responden laki - laki $(37,1 \%)$ sedangkan jenis kelamin responden perempuan lebih banyak sebesar $(62,9 \%)$. Sebagian besar usia responden terletak pada batas usia 18 - 22 tahun (86,3\%), sementara urutan kedua berada diusia $23-27$ tahun sebesar $(19,6 \%)$.

Sedangkan menurut jenis pekerjaan, sebagian besar responden berstatus pelajar / mahasiswa dengan presentase $(65,7 \%)$, sementara sisanya adalah berstatus sebagai pekerja dengan presentase $(34,3 \%)$. Jenis produk fashion responden sebagian besar membeli produk Uniqlo dengan presentase (45,7\%), untuk urutan kedua ada produk HnM sebesar $(26,4 \%)$, kemudian di urutan ketiga responden membeli produk zara sebesar (23,6\%), untuk produk lain - lainnya sebesar (4,3\%). Pendapatan responden sebagian besar berada di kisaran diatas $>1,5 \mathrm{jt}-2 \mathrm{jt}$ sebesar $(52,1 \%)$, kemudian diuruatan kedua berada pada kisaran 1jt-1,5jt (35\%), lalu diurutan ketiga kisaran 500-1jt (7,9\%) dan urutan keempat pada kisaran $<500$ rb sebesar $(5 \%)$.

Tabel 2. Hasil Analisis Regresi Linier Berganda

\begin{tabular}{cccccc}
\hline Variabel & Koefisien Regresi & thitung & F $_{\text {hitung }}$ & $\mathrm{R}$ square & Sig \\
\hline Konstanta & 28.332 & & 48.640 & 0.415 & 0.000 \\
Shopping Lifestyle & 0.993 & 6.072 & & & 0.000 \\
Hedonic Motives & 0.060 & 0.563 & & & 0.000 \\
\hline
\end{tabular}

Sumber: Data Pribadi, 2020

Dari hasil tabel menunjukan bisa dibuat persamaan regresei linier berganda sebagaimana berikut: $Y=28,332+0,993 X 1+0,060 \mathrm{X} 2$

Dari hasil analisis regresi linier berganda yang masih berbentuk angka dapat dijelaskan kedalam bahasa yang untuk di pahami, untuk penjelasannya sebagai berikut:

a. Konstan 28,332

Pada nilai konstanta ini sebesar 28,332, artinya jika pada variabel shopping lifestyle dan hedonic motives bernilai nol, maka impulse buying behavior akan sebesar 28,332 sehingga bisa disimpulkan bahwa tanpa ada variabel shopping lifestyle dan hedonic motives maka impulse buying behavior akan sebesar 28,332 .

b. $(\mathrm{b} 1)=0,993$

Jadi pada variabel shopping lifestyle mempunyai pengaruh dengan impulse buying behavior sebesar 0,993 
c. $(\mathrm{b} 2)=0,060$

Jadi pada variabel hedonic motives memiliki pengaruh dengan impulse buying behavior sebesar 0,060

Tabel 3. Hasil Uji Parsial (Uji T)

\begin{tabular}{|c|c|c|c|c|c|c|}
\hline & \multirow[t]{2}{*}{ Model } & \multicolumn{2}{|c|}{$\begin{array}{l}\text { Unstandardized } \\
\text { Coefficients }\end{array}$} & \multirow{2}{*}{$\begin{array}{c}\text { Standardized } \\
\text { Coefficients } \\
\text { Beta }\end{array}$} & \multirow[t]{2}{*}{$\mathrm{t}$} & \multirow[t]{2}{*}{ Sig. } \\
\hline & & B & Std. Error & & & \\
\hline \multirow{3}{*}{1} & (Constant) & 28.332 & 2.479 & & 11.427 & .000 \\
\hline & Lifestyle & .993 & .163 & .601 & 6.072 & .000 \\
\hline & Hedonic Motives & .060 & .106 & .056 & .563 & .000 \\
\hline
\end{tabular}

Sumber: Data Pribadi, 2020

a. Shopping Lifestyle memiliki nilai t 6,072 dengan nilai probabilitas signifikansi sebesar 0,000 . Signifikansi t lebih kecil dari a $(0,05)$, dengan ini Ha diterima. Maka antara shopping lifestyle terhadap impulse buying behaviour mempunyai pengaruh signifikan.

b. Hedonic motives memiliki nilai t 0,563 dengan nilai probabilitasnya signifikan sebesar 0,000 . Signifikansi t lebih besar dari a $(0,05)$ atau 5\%, dengan ini Ha diterima, maka antara hedonic motives terhadap impulse buying behaviour mempunyai pengaruh signifikan.

Tabel 4. Hasil Uji Simultan (Uji F)

\begin{tabular}{cccccc}
\hline Model & Sum of Squares & $\mathrm{df}$ & Mean Square & F & Sig. \\
\hline Regression & 1882.228 & 2 & 941.114 & 48.640 & .000 \\
Residual & 2650.743 & 137 & 19.348 & & \\
Total & 4532.971 & 139 & & & \\
\hline
\end{tabular}

Sumber: Data Pribadi, 2020

Dari tabel 16, terlihat bahwa nilai signifikansi $\mathrm{F}=0,000<\mathrm{a}=0,05$ yang artinya Ha diterima, dengan kata lain shopping lifestyle, hedonic motives secara simultan berpengaruh secara signifikan terhadap impulse buying behaviour.

Tabel 5. Hasil Uji Koefisien Determinasi $\left(\mathrm{R}^{2}\right)$

\begin{tabular}{ccccc} 
Model & $\mathrm{R}$ & $\mathrm{R}$ Square & Adjusted R Square & Std. Error of the Estimate \\
\hline 1 & $.644^{\mathrm{a}}$ & .415 & .407 & 4.399 \\
\hline
\end{tabular}

Sumber: Data Pribadi, 2020

Hasil menunjukan, bahwasannya didapatkannya nilai adjusted $R$ square adalah 0,407. Maka $41 \%$ variasi variabel terikat yaitu impulse buying behavior maka bisa dijelaskan oleh 2 variasi yaitu shopping lifestyle serta hedonic motives. Sedangkan sisanya (100\% - 41\% = 59\%) dijelaskan oleh variabel lain di luar dari variabel penelitian ini.

Tabel 6. Hasil Uji Normalitas Sebaran

\begin{tabular}{cccc}
\hline Variabel & Kolmogorov-Smirnov (Z) & Signifikansi (p) & Keterangan \\
\hline $\begin{array}{c}\text { Impules Buying } \\
\text { Motives }\end{array}$ & 0,864 & 0,444 & Terdistribusi Normal \\
Shoppoing LifeStyle & 2,476 & 0,000 & Tidak Terdistribusi \\
Normal \\
Hedonic Motives & 1,963 & 0,001 & Tidak Terdistribusi \\
& & & Normal \\
\hline
\end{tabular}

Sumber: Data Pribadi, 2020

Menunjukkan hasil, bahwasannya uji normalitas dapat dijelaskan bahwa data tersebut ada dua variabel yang nilainnya dibawah nilai probabilitas yang menyebabkan variabel tersebut memiliki distribusi yang tidak normal, yaitu pada variabel shopping lifestyle dan hedonic motives. Sedangkan

This work is licensed under a Creative Commons

Attribution-ShareAlike 4.0 International License. (CC BY SA)
Volume 03 Nomor 01 Januari 2021 
pada variabel impulse buying behaviour memiliki sebaran data yang berdistribusi normal dan memiliki arti bahwa nilai signifikansi lebih dari nilai probabilitas atau signifikansi variabel impulse buying behaviour diatas (>) 0,05. Nilai signifikansi ini sesuai yang di kemukakan dari buku analisis statistik oleh

Abdul

Muhid

(2012)

Tabel 7. Hasil Uji Homogenitas

\begin{tabular}{ccccc}
\hline Variabel & $\mathrm{df}$ & Mean Square & $\mathrm{F}$ & Sig \\
\hline Lifestyle dengan Impulse Buying Behavior & 15 & 150.204 & 8.169 & 0.00 \\
$\begin{array}{c}\text { Hedonic Motives dengan Impulse Buying } \\
\text { Behavior }\end{array}$ & 22 & 76.967 & 3.171 & 0.00
\end{tabular}

Sumber: Data Pribadi, 2020

Berdasarkan tabel diatas diperoleh hasil perhitungan lifestyle dengan impulse buying behaviour nilai $\mathrm{F}$ 8,169 dengan signifikansi $(\mathrm{p})<0,05$ artinya bahwa varians data tersebut adalah homogen, sedangkan Hedonic Motives dengan Impulse Buying Behavior memperoleh hasil F sebesar 3,171 dengan nilai signifikansi $(\mathrm{p})<0,05$ bahwa varians pada data tersebut adalah homogen.

\section{Pembahasan}

Dari hasil penelitian yang telah dilakukan menunjukan hasil bahwasanya shopping lifestyle memiliki terhadap impulse buying behavior mempunyai pengaruh signifikan. Hasil ditunjukkan dengan nilai t 6.072 dan signifikansi sebesar $0,000<a(0,05)$. Penelitian juga sejalan dengan hasil dari Setyaningrum dkk (2016), Andryansyah \& Arifin (2018), Rahmawati (2018), yang menunjukan bahwa shopping lifestyle terhadap impulse buying behavior mempunyai pengaruh yang signifikan.

Setyaningrum, dkk (2016) menjelaskan bahwa shopping terhadap variabel impulse buying behavior mempunyai pengaruh signifikan dengan menunjukan nilai koefisien jalur (B) sebesar 0,411 dengan probabilitasnya sebesar $0,000(\mathrm{p}<0,05)$. Levy (2009) menyatakan shopping lifestyle yaitu merupakan lifestyle yang berlandaskan pada cara bagaiamana individu tersebut dalam hidup, bagaimana individu mengalokasikan waktu serta uang yang dimilikinya, kemuadian tindakan pemembelian yang dilakukan oleh individu, sampai sikap dalam tempat lingkungan yang mereka tinggali.

Sedangkan Loundon dan Britta (1993) mengatakan bahwa impulse buying behavior terdapat tiga bagian karatersitik, dinyatakannya merk karakteristiknya yang bisa terpengaruh dalam tindakan membeli yang spontan. Dari merk karateristiknya itulah mennjadikan bisa memengaruhi tindakan pembelian yang tidak terencana seperti harga yang murah, kemudian dengan adanya harga yang murah serta ada potongan harga itu menjadikan individu itu tertarik yang menjadi memenuhi gaya hidup dalam tindak pembeliannya.

Dari hipotesis ini dapat disimpulkan bahwa shopping lifestyle didalam individu disaat melakukan pembelian bisa menjadikan salah satu alasan mendasar yang tepat guna toko dalam menaikan pendapatannya lewat adanya tindakan membeli konsumen yang impulsive. Serta shopping lifestyle bisa menjadikan salah satu alasan pengaruh yang mendasar dari terjadinya impulsive.

Dari hasil penelitian yang telah dilakukan bahwasanya hedonic motives terhadap impulse buying behavior mempunyai pengaruh signifikan. Ditunjukkan dengan nilai t 0.563 dan signifikan sebesar $0.000<$ nilai (p) 0,05. Hasil penelitian yang telah dilakukan, sejalan pada penelitian Kosyu, Hudayat \& Abdillah (2014), yang menjelaskan bahwasanya hedonic motives terhadap impulse buying behavior mempunyai pengaruh signifikan.

Kosyu, Hudayat \& Abdillah (2014) mengatakan bahwa seseorang berbelanja mengalami emosi yang positif dalam belanja produk maupun merk tertentu dengan tidak adanya rencana yang matang dari catatan yang telah ditentukan. Semuel (2005) menyatakan bahwasanya tindakan belanja yang dilakukan tanpa adanya perencanaan, dengan ini kegiatan untuk mengalokasikan uangnya menjadi tidak terkontrol, dan banyak barang yang substansial yang sebenarnya konsumen itu tidak memperlukannya.

Sedangkan Scarpi (2006) menjelaskan hedonic shopping sebagai nilai dari pengalaman dalam pembelian ini meliputi fantasi, kemudian reaksi dari rangsangan, kesenangan, kepuasan dalam indvidu.

This work is licensed under a Creative Commons

Attribution-ShareAlike 4.0 International License. (CC BY SA)

Volume 03 Nomor 01 Januari 2021 
Kepuasannya timbul disaat konsumen melakukan belanja dengan hedonis, menimbulkan tindakan dalam membeli barang selalu terus menerus. Penawaran yang memikat seperti adanya diskon yang ditawarkan oleh toko tersebut, menjadikan konsumen selalu melakukan pembelian melebihi kebutuhan yang seharusnya. Gultekin dan Ozer (2012) juga menjelaskan bahwasanya hedonic shopping motives terhadap impulse buying mempunyai pengaruh signifikan.

Dari hipotesis ini dapat disimpulkan bahwa hedonic motives dalam individu di saat melakukan pembelian ini bisa menjadikan salah satu alasan yang dasar dalam pengaruh konsumen melakukan tindakan belanja dengan perilaku impulsive.

Hasil pengujian shopping lifestyle serta hedonic motives terhadap impulse buying behavior secara simultan berpengaruh signifikan. Hal ini ditunjukkan nilai signifikansi $\mathrm{F}=48.640$ serta signifikansi $0,000<\alpha=0,05$ pada pengujian simultan (uji F). Penelitian Rahmawati (2018) menjelaskan bahwasanya shopping lifestyle serta hedonic motives terhadap impulse buying behavior berpengaruh signifikan. Dengan ini bisa disimpulkan bahawa hedonic motives akan terciptanya gairah dengan melakukan pembelian produk fashion karena konsumen akan merasa memiliki banyak model fashion yang lagi trend. Pada saat konsumen melakukan pembelian, konsumen mempunyai emosi yang positif disaat membeli produk dengan tidak ada perencaan sebelumnya. Semuel (2005) menyatakan jika pembelian tidak adanya perencanaan, dengan kegiatan mengalokasikan uang yang tidak terkontrol, serta konsumen sering membeli barang secara substansial.

Dari hasi penelitian yang telah dilakukan, sejalan dengan penelitian Atchariyachanvanich dan Hitosi Okada (2007) menunjukan bahwasanya lifestyle individu seperti berinteraksi dengan orang disekitar lingkungannya, kemudian cara hidupnya berinovasi, serta lifestyle berdasarkan dari melihat harga. Dari hasil perhitungan telah teruji dalam mempengaruhi perilaku pembelian. Dengan ini, hipotesis dari penelitian bisa diambil kseimpulan bahwasanya dari variabel shopping lifestyle serta hedonic motives terhadap impulse buying behavior terdapat besaran nilai yang sangat besar pengaruhnya.

\section{Kesimpulan}

Hasil dari penelitian serta pembahasan yang sudah diuraikan, maka kesimpulan untuk penelitian bahwasanya shopping lifestyle serta hedonic motives terhadap impulse buying behavior memiliki pengaruh signifikan.

Adapun beberapa saran yang bisa peneliti berikan sebagai berikut : 1) Bagi Pengembangan Industri dan Organisasi; diharapkan untuk bisa memberikan manfaat dan bisa memberikan tambahan wawasan terhadap keilmuan psikologi, terutama pada psikologi industri dan organisasi, 2) Bagi Peneliti Selanjutnya; diharapkan bisa menjadi bahan refrensi dalam melakukan penelitian tentang pembelian impulsif, shopping lifestyle dan hedonic motives dengan memberikan variabel serta subyek yang berbeda guna meningkatkan hasil penelitian yang sudah ada. 3) Bagi Konsumen Produk Fashion; diharapkan bisa lebih selektif dalam membeli produk fashion yang ingin di beli, lebih mementingkan kebutuhan daripada hanya keinginan untuk membeli. Karena barang yang sudah terbeli agar tidak menjadi sia-sia. 4) Bagi Unit Pengusaha Produk Fashion; diharapkan bisa meningkatkan strategi pemasaran untuk semakin meningkatkan daya beli konsumen pada produk fashion.

\section{Daftar Pustaka}

Abdul, Muhid. (2012). Analisis Statistik. Sidoarjo: Zifatama.

Arifianti, Ria. (2010). Pengaruh Atribut Supermarket Terhadap Impulse Buying (survei pada Supermarket Di Kota Bandung). Jurnal Strategic, Vol 9, 17.

Astrid Gisela Herabadi. (2003). Perbedaan Individual dalam Kecenderungan Belanja Impulsif: Sarat Emosi dan Pendek Pikir. Jurnal Psikologi, (Volume 12 Nomor 2).Hlm. 58-70.

Betty R. Jackson. "Audit Information Dissemination, Taxpayer Communication, and Compliance: An Experimental Approach." IRS Research Conference, Washington, DC. 2004.

Darma, L. A., \& Japarianto, E. (2014). Analisa Pengaruh Hedonic Shopping Value terhadap Impulse Buying dengan Shopping Lifestyle dan Positive Emotion sebagai variable Intervening pada Mall Ciputra World Surabaya. Jurnal Manajemen Pemasaran, Vol. 8, No. 2, Oktober 2014. 
Hirschman, E.C. dan Holbrook, M.B. (1982). The experiential aspects of consumption: consumer fantasies, feelings and fun, Journal of Consumer Research, Vol. 9 (No. 2) pp. 132-40.

https://radarsurabaya.jawapos.com/read/2019/03/05/123235/daya-beli-naik-ritel-fashion-asing-di-jatimtumbuh-15-persen Diakses pada 1 Maret 2020.

https://money.kompas.com/read/2019/04/04/123029126/ Diakses pada 1 Maret 2020

Japarianto, E., dan Sugiharto., S. 2011. "Pengaruh Life Style dan fashion Involvement Terhadap Impulse buying Behavior Masyarakat Higj Income Surabaya”, April 2011.

Levy, Michael \& Weitz, Barton A., (2009). Retailing Management. New York, Ameriva: McGrawHill/Irwin.

Loudon, D.L, dan Della Bitta, A.J, 1993, Consumer Behavior: Concepts and Application, Singapore: Mc.Grow-Hill, Inc.

Lubis, I. F. (2017). Analisis Hubungan Antara Inflasi Dan Pertumnuhan Ekonomi: Kasus Indonesia. QE Journal Vol. 03 No.01, 41-52

Lumintang, Fenny Felicia, 2012, Pengaruh Hedonic Motives terhadap Impulse Buying Melalui Browsing dan Shopping Lifestyle pada Online Shop, Jurnal Universitas Katolik Widya Mandala Surabaya, Vol. 1, No.6, ISSN: 2303 162X.

Maruf, H. (2006). Pemasaran Ritel. In Jakarta: Gramedia Pustaka Utama. https://doi.org/10.1007/s10872-006-0051-9.

Mowen, John C dan Minor, Micheal. (2012). Perilaku Konsumen dialih bahasakan oleh Dwi Kartika Yahya. Jakarta: Erlangga.

Nuryaman \& Veronica Christina. (2015). Metodologi Penelitian Akuntansi dan Bisnis Teori dan Praktek. Bogor: Ghalia Indonesia.

Overby, J.W. and Lee, E.J. 2006. The Effects Of Utilitarian And Hedonic Online Shopping Value On Consumer Preference And Intentions. J Business Research, 59: 1160-1166.

Rook, D. W., \& Hoch, S. J. (1985). Consuming impulses. Advances in Consumer Research, 12, 23-27.

Scarpi, D. 2006. Pengaruh Shopping Lifestyle, Fashion Involvement dan Hedonic Shopping Terhadap Impulse Buying Behavior Pelanggan. Jurnal Ilmu dan Riset Manajemen Desember 2015. Vol. 4, No. 12.

Semuel Hatane, 2006. "Dampak Respon Emosi Terhadap Kecenderungan Perilaku Pembelian Impulsif Konsumen Online dengan Sumberdaya yang Dikeluakan dan Orientasi Belanja Sebagai Variabel Mediasi”. Jurnal manajemen dan kewirausahaan.Vol.8.No.2.

Sugiyono. 2013. Metode Penelitian Pendidikan Pendekatan Kuantitatif, Kualitatif, dan R\&D. Bandung: Alfabeta.

Utami, Christina Widya. (2010). Manajemen Ritel: Strategi dan Implementasi Operasional Bisnis Ritel Modern di Indonesia, Edisi 2, Penerbit Salemba Empat, Jakarta.

Verplanken, B., \& Sato, A. (2011, March 26). The psychology of impulse buying: an integrative selfregulation approach. J Consum Policy, hal. 197-210. 